\title{
Biochemical Markers Present in a Population Susceptible to Suffering From Metabolic Syndrome
}

\author{
Anderson Díaz-Pérez ${ }^{1,2}$, Consuelo Roldán Menco $^{2}$, Zorayda Barrios Puerta ${ }^{2}$, María Badillo-Viloria ${ }^{1,2}$, \\ Elkin Navarro-Quiroz ${ }^{1,3}$, Zuleima Yañez Torregroza ${ }^{1} \&$ Carmenza Leonor Mendoza Cataño $^{4}$ \\ ${ }^{1}$ Faculty of Health Sciences, Social and Human Sciences, Simón Bolívar University, Barranquilla, Colombia. \\ ${ }^{2}$ Faculty of Health Sciences, University Corporation Rafael Núñez, Cartagena, Colombia \\ ${ }^{3}$ ACCONP Foundation - E Biotechnologies, Cartagena, Colombia \\ ${ }^{4}$ Faculty of Social and Human Sciences, Universidad de la Guajira, Colombia \\ Correspondence: Anderson Díaz-Pérez, Faculty of Health Sciences, Social and Human Sciences, Simón Bolívar \\ University, Barranquilla, Colombia. Tel: 57-301-428-8467. E-mail: ander2711@gmail.com
}

Received: February 10, 2018 Accepted: February 28, 2018 Online Published: March 13, 2018

doi:10.5539/gjhs.v10n4p85 URL: https://doi.org/10.5539/gjhs.v10n4p85

\begin{abstract}
Objective: To determine the prevalence of metabolic syndrome (SM) according to Adult Treatment Panel III ATPIII and its relation with uric acid concentration and C-reactive protein, in people aged from 45 to 60 years old from the Getsemaní neighborhood of Cartagena city, Colombia.
\end{abstract}

Materials and Methods: Type of study: Observational, Descriptive-Correlation. Population of 802 inhabitants from the Getsemaní neighborhood of Cartagena city. We analyzed 302 inhabitants from a random sample with 95\% confidence level and 5\% of error level. The ATP III diagnostic criteria were applied, the applied instrument had basic data about the general context (social, demographic, economic aspects, family history, work activity and its physical characteristics: weight, waist circumference, blood pressure, calculation of BMI), as well diagnostic tests as: glycaemia, total cholesterol, triglycerides, HDLc, LDLc, uric acid, ultrasensitive C-reactive protein.

Results: The population susceptible to metabolic syndrome presented a prevalence of $18 \%$. The most prevalent metabolic syndrome factor was abdominal obesity with $85 \%$, followed by an increase in triglycerides by $76 \%$.

Conclusion: When applying the ATP III criteria, the prevalence of metabolic syndrome was considered high. There was no significant association of C-reactive protein values with the possibility of developing metabolic syndrome in both men and women, but uric acid results were found to be correlated in the group of women susceptible to MS with a $\mathrm{p}=0.0022$.

Keywords: hypertension, uric acid, obesity, risk factors

\section{Introduction}

The Metabolic Syndrome (MS) represents a problem for people's health. It not only occurs in adults, but also affects young people (Heiss et al., 2014; Biben, Orkin, \& Bopp, 2016) and is associated with other diseases such as depression (Virtanen et al., 2017). The most important cause of SM is the poor management of lifestyle due to unbalanced diet, sedentary lifestyle and family history of chronic diseases (Rodríguez \& García, 2016; Rosales, Rivas, \& Troconis, 2017; Bell Castillo et al., 2017).

SM is a pathological condition associated with insulin resistance and hyperinsulinemia that presents a high risk of developing type 2 diabetes mellitus and atherosclerotic cardiovascular disease (Carvajal, 2017). This makes it a subject of debate in the medical community because it is related to diseases that cause higher mortality rates worldwide (Cabalé Vilariño, Sánchez Serrano, Gutiérrez Carbonell, \& Flores Sánchez, 2011). Its prevalence varies according to factors such as gender, age, ethnicity; it is between $15 \%$ and $40 \%$, being higher in the population of Hispanic origin (Cabalé Vilariño et al., 2011; Heiss et al., 2014; Aguilar, Bhuket, Torres, Liu, \& Wong, 2015). In 2001 the National Cholesterol Education Program (NCEP) in the Adult Treatment Panel III (ATPIII) determined that three or more of the following diagnostic criteria must be met in order to diagnose MS: high abdominal circumference ( $>102 \mathrm{~cm}$ in men and $>88 \mathrm{~cm}$ in women), triglycerides $\geq 150 \mathrm{mg} / \mathrm{dl}$, low HDL (men $<40 \mathrm{mg} / \mathrm{dl}$ and women HDL $<50 \mathrm{mg} / \mathrm{dl}$ ), high blood pressure $\geq 130 / 85 \mathrm{~mm} \mathrm{Hg}$, glycaemia $>110 \mathrm{mg} / \mathrm{dl}$ including Diabetes Mellitus (Castro \& Yaqueline, 2016; Giraldo, Perdomo, Aristizábal, \& Restrepo, 2017; Iliff, 2001). 
In 2004, with the update of the American Diabetes Association, fasting glycemia was modified to $100 \mathrm{mg} / \mathrm{dl}$ for diabetes (Kahn, 2003), likewise; thrombogenesis, inflammation, uric acid, stress, smoking, and sedentary lifestyle are considered other factors for undergoing this syndrome (Carvajal, 2017; Pineda, 2008). In 2012, the American Diabetes Association (ADA) and the European Association for the Study of Diabetes (EASD) published a consensus statement on the management of hyperglycemia in patients with type 2 diabetes (DM2) (Díaz, 2015). The association of hyperuricemia and systemic arterial hypertension has long been recognized as one of the biomarkers for early detection (Srikanthan, Feyh, Visweshwar, Shapiro, \& Sodhi, 2016). This is based on the following observations (Jossa et al., 1994): the prevalence of hyperuricemia is approximately 20 to $40 \%$ in untreated hypertensive people and approximately 50 to $70 \%$ of patients with renal insufficiency and hypertension; gout prevails between 2 and $12 \%$ of patients with hypertension, increasing the prevalence of hyperuricemia with the increase in blood pressure in the general population (Borghi et al., 2015; Culleton, Larson, Kannel, \& Levy, 1999; Melnyk, 2017).

Due to the difficulty in distinguishing the cause and the pathological basis of the relationship between hyperuricemia and hypertension, it has been found that renal depuration of uric acid depends on tubular secretion and post-secretory reabsorption, which has been reported to be impaired in patients with arterial hypertension (Kang \& Nakagawa, 2005). Within the ARIC study (Ballantyne et al., 2005; Garg et al., 2017), factors that predispose to hyperinsulinemia were taken, and it was found that hyperuricemia $(>6.4 \mathrm{mg} / \mathrm{dl})$ was positively associated with hyperinsulinemia and MS, since it is a demonstrable factor that indicates a high probability of developing these two medical conditions. In MS pathophysiology, metabolism alterations are implicated, such as the glycolipid profile, among other pro-inflammatory and prothrombotic markers. (Esser, Legrand-Poels, Piette, Scheen, \& Paquot, 2014; Testa et al., 2015); which helped to determine the increase in prevalence significantly related to the increase in uric acid concentrations (Jiménez et al., 2009; Valenzuela, 2016). Other studies demonstrate the association between MS and / or Insulin resistance with the increase of ultrasensitive C-reactive protein (hsCRP), a well-known marker of inflammation (Fernández, 2016; Han et al., 2002; Sakkinen, Wahl, Cushman, Lewis, \& Tracy, 2000).

Therefore, the objective was to determine the prevalence of metabolic syndrome according to ATPIII and its relationship with the concentration of uric acid and ultrasensitive C-reactive protein in people aged from 45 to 60 years in the Getsemaní neighborhood of Cartagena city, Colombia.

\section{Materials and Methods}

Descriptive study with a correlation component, the target population was 802 inhabitants of the Getsemaní neighborhood of the city of Cartagena de Indias between the ages of 45 and 60 years. The sample was of 302 inhabitants randomly selected, with a $95 \%$ confidence level and an error level of $0.05 \%$. Participants were previously informed and signed informed consent. The study was approved by the research committee. An instrument was applied prior internal validation with a Cronbach's alpha coefficient of 0.75 . The questions included basic data such as sociodemographic, economic, family history, work activity, among others. Clinical data were taken, such as: weight, waist circumference, blood pressure measurement, sedentary lifestyle, calculation of the body mass index (BMI). Blood pressure was determined by the average of two measurements using the participant's right arm, taken 5 minutes apart with the participant seated (National Joint Committee VII). The height was measured with a stadiometer and the weight with a conventional balance, without footwear. The waist perimeter was measured with a measuring tape. The sedentary lifestyle was defined as the lack of physical activity in free time, in the last month, during 2 hours and a half per week, in sessions of at least 30 minutes. The practices investigated were: walking, jogging, cycling, playing soccer, volleyball, dancing. Blood samples were taken after fasting 8-12 hours to determine levels of glycaemia, total cholesterol, triglycerides, HDLc, LDLc, uric acid, ultrasensitive C-reactive protein, calculation of LDLc by the Friedewald formula. Subsequently, they were centrifuged at $2500 \mathrm{rpm}$ for 15 minutes, refrigerating until they were measured. All determinations were made with a Mindray BS-200 equipment, with normal and high-level control sera from HUMAN, complying with all the quality controls. Endpoint tests were used, for quantification (hsCRP) the method used was turbidimetric. For the diagnosis of metabolic syndrome, the NCEP / ATP III criteria were applied (Expert Panel on Detection, 2001). For glycaemia, the update of the American Diabetes Association 2004 was used, where the fasting glycaemia was modified to $100 \mathrm{mg} / \mathrm{dl}$ (Association, 2014; Iliff, 2001).

The processing of the information and data statistical analysis were performed using Excel 2007. The descriptive statistical analysis of the data was expressed as prevalences. mean, mode and standard deviation. Correlation analyzes were performed by calculating the Pearson (r) calculation with a $95 \%$ of significance and a $p$-value of $\leq 0.05$, for which the SPSS $19.0{ }^{\circledR}$ for Windows was utilized. 


\section{Results}

Of 302 people between 45 and 60 years old 125 (41\%) were male and 177 (59\%) female. The average age was 51 years (SD 4.8), average weight 72.9 (SD 14.7), the average waist circumference of 88.9 (SD 11.7), and a BMI of $35.1 \mathrm{Kg} / \mathrm{m}^{2}$ (SD 14.5) related to obesity. In relation to the mean arterial pressure was $88 \mathrm{mmHg}$ (SD 7.4). The most frequent work activity was commerce with 67 (22\%) and household activities with 97 (32\%). In turn, when questioned about sedentary lifestyle, it was found that 193 (64\%) of the people stated that they performed some of the practices investigated, and 109 (36\%) people do not perform them, being able to consider them as sedentary.

A prevalence of metabolic syndrome of $54(18 \%)$ was found in this group of people who presented more than three risk factors, according to the criteria of ATP III, while 248 (72\%) people had less than three risk factors, where according to Adult Treatment Panel III (ATPIII) it allows to diagnose a patient with the presence of three or more alterations in the same individual.. The prevalence of metabolic syndrome was higher in women $39(72 \%)$, than in men $15(28 \%)$. The most relevant risk factor was the abdominal perimeter in $46(85 \%)$, followed by the HDL concentration in $43(79.6 \%)$ and third the concentration of decreased triglycerides in $41(75.9 \%)$. (Table 1)

Table 1. Susceptibility and prevalence of suffering from metabolic syndrome (MS) on the total population and by sex according ATP III criteria

\begin{tabular}{lllllll}
\hline $\begin{array}{l}\text { Risks factors according } \\
\text { ATP III criteria }\end{array}$ & n (\%) & $\begin{array}{l}\text { Susceptible or not of } \\
\text { suffering from MS - ATP III }\end{array}$ & n (\%) & $\begin{array}{l}\text { SM prevalence } \\
\text { according ATP III }\end{array}$ & n (\%) \\
\hline Abdominal perimeter & $46(85,10)$ & Yes & $54(18)$ & Men & $15(28)$ \\
Triglycerides $>\mathbf{1 5 0}$ & $41(75,90)$ & No & $248(82)$ & Women & $39(72)$ \\
HDL & $43(79,60)$ & Total & $302(100)$ & Total & $54(100)$ \\
High blood pressure & $10(18,50$ & & & & \\
Glycaemia & $12(22,20)$ & & & & & \\
Total & $152(50,33)$ & & & & & \\
\hline
\end{tabular}

n: Frequency. (\%): Percentage.

The comparison of the anthropometric measurements between men and women with metabolic syndrome did not show a significant difference. The variables of the biochemical tests in both sexes show that there is marked difference in glycaemia, the average value in men was $121.6 \mathrm{mg} / \mathrm{dl}$ and in women of $90.4 \mathrm{mg} / \mathrm{dl}$; In relation to triglycerides, a mean of $228.1 \mathrm{mg} / \mathrm{dl}$ was found in men and $170.6 \mathrm{mg} / \mathrm{dl}$ in women. According to the results of the ultra-sensitive C reactive protein, the average in men was $9.6 \mathrm{mg} / \mathrm{l}$, and in women $5.7 \mathrm{mg} / \mathrm{l}$, increased in both sexes as a possible predictor of an inflammatory event. (Table 2)

Table 2. Results of the biochemical tests of the susceptible and prevalent population of suffering metabolic syndrome according to the ATP III criteria

\begin{tabular}{|c|c|c|c|c|c|c|}
\hline \multicolumn{4}{|l|}{ Male n (\%) } & \multicolumn{3}{|c|}{ Female n (\%) } \\
\hline \multirow{2}{*}{ Glucose (mg/dl) } & Mean & $\mathrm{Sd}$ & CI 95\% (LL-UP) & Mean & $\mathrm{Sd}$ & CI 95\% ((LL-UP) \\
\hline & 121,667 & 84,5701 & $(74,8332-168,5)$ & 90,4872 & 35,4637 & $(78,9911-101,983)$ \\
\hline Triglycerides (mg/dl) & 228,133 & 51,1425 & $(199,812-256,455)$ & 170,667 & 55,6159 & $(152,638-188,695)$ \\
\hline Cholesterol (mg/dl) & 230,067 & 117,209 & $(165,158-294,975)$ & 183,308 & 50,4356 & $(166,958-199,657)$ \\
\hline HDL (mg/dl) & 39,84 & 9,29353 & $(34,6934-44,9866)$ & 41,8872 & 8,86309 & $(39,0141-44,7603)$ \\
\hline LDL (mg/dl) & 122,733 & 36,5444 & $(102,496-142,971)$ & 111,026 & 35,4828 & $(99,5234-122,528)$ \\
\hline Uric acid (mg/dl) & 5,66933 & 1,21366 & $(4,99723-6,34144)$ & 4,72231 & 1,31608 & $(4,29568-5,14893)$ \\
\hline $\begin{array}{l}\text { Ultra sensitive } C \\
\text { reactive protein } \\
(\mathrm{mg} / \mathrm{dl})\end{array}$ & 9,68667 & 28,6353 & $(6,1710-25,5444)$ & 5,75641 & 6,09775 & $(3,77975-7,73308)$ \\
\hline Total & $15(28)$ & $54(100)$ & & $39(72)$ & & \\
\hline
\end{tabular}

n: Frequency. (\%): Percentage. Sd: Standard deviation. LL: Lower limit. UL: Upper limit. 
Regarding the correlation of C-reactive protein and uric acid in women susceptible of suffering metabolic syndrome showed that there is no correlation between these and the other biochemical markers such as glycaemia and lipid profile. However, uric acid levels correlate moderately with $\mathrm{C}$-reactive protein levels $(\mathrm{r}=0.4756, \mathrm{p}=$ 0.0022). In men, levels of C-reactive protein and uric acid do not correlate with biochemical markers. (Table 3)

Table 3. Comparison of the correlational analysis of biochemical markers in women and men

\begin{tabular}{|c|c|c|c|c|c|c|}
\hline Biochemical Markers & $\begin{array}{l}\text { Glucose } \\
(\mathrm{mg} / \mathrm{dl})^{\hat{\gamma}}\end{array}$ & $\begin{array}{l}\text { Total Cholesterol } \\
(\mathrm{mg} / \mathrm{dl})^{\dagger}\end{array}$ & $\begin{array}{l}\text { Total Cholesterol } \\
(\mathrm{mg} / \mathrm{dl})^{\gamma}\end{array}$ & $\begin{array}{l}\mathrm{HDL} \\
(\mathrm{mg} / \mathrm{dl})^{+}\end{array}$ & $\begin{array}{l}\mathrm{LDL} \\
(\mathrm{mg} / \mathrm{dl})^{\hat{\beta}}\end{array}$ & $\begin{array}{l}\text { Uric acid } \\
(\mathrm{mg} / \mathrm{dl})^{+}\end{array}$ \\
\hline Glucosa (mg/dl) & & 0,11 & $0,76^{* *}$ & 0,05 & $0,63^{*}$ & 0,02 \\
\hline Total Cholesterol (mg/ dl) & $0,76^{* *}$ & & & $0,4^{*}$ & $0,67^{* * *}$ & 0,001 \\
\hline LDL (mg/dl) & $0,62^{*}$ & $0,65^{* *}$ & $0,66^{* *}$ & $0,5^{* *}$ & & $-0,08$ \\
\hline $\begin{array}{l}\text { Ultra sensitive } C \text { reactive } \\
\text { protein }(\mathrm{mg} / \mathrm{dl})\end{array}$ & 0,00 & 0,00 & $-0,05$ & 0,03 & 0,03 & $0,48^{* *}$ \\
\hline
\end{tabular}

${ }^{*} \mathrm{p} \leq 0.01 ; * \mathrm{*} \leq 0.001 ;{ }^{\left({ }^{*}\right)}$ Male $(\mathrm{n}=15) ;{ }^{(+)}$Female $(\mathrm{n}=39)$.

As for the anthropometric measurements in women, a weak positive correlation was found between uric acid and weight $(r=032117, p=0.045)$. With the rest of the anthropometric variables, there is no significant correlation between uric acid and C-reactive protein (Table 4). The results did not have statistical significance in the correlation between uric acid and C-reactive protein and the other anthropometric variables in men susceptible to suffering metabolic syndrome. (Table 4)

Tabla 4. Comparison of the correlational analysis of biochemical markers and anthropometric measurements in women and men

\begin{tabular}{|c|c|c|c|c|c|c|c|c|}
\hline $\begin{array}{l}\text { ANTHROPOMETRIC } \\
\text { VARIABLES }\end{array}$ & $\begin{array}{l}\text { Weight } \\
(\mathrm{Kg})^{\varphi}\end{array}$ & $\begin{array}{l}\text { Weight } \\
(\mathrm{Kg})^{\delta^{2}}\end{array}$ & $\begin{array}{l}\text { BMI } \\
(\mathrm{Kg} / \mathrm{m} 2)^{+}\end{array}$ & $\begin{array}{l}\text { BMI } \\
(\mathrm{Kg} / \mathrm{m} 2)^{2}\end{array}$ & $\begin{array}{l}\text { Systolic } \\
\text { blood } \\
\text { pressure } \\
(\mathrm{mmHg})^{\text {P }}\end{array}$ & $\begin{array}{l}\text { Diastolic } \\
\text { blood } \\
\text { pressure } \\
(\mathrm{mmHg})^{\text {क }}\end{array}$ & $\begin{array}{l}\text { Diastolic } \\
\text { blood } \\
\text { pressure } \\
(\mathrm{mmHg})^{\circ}\end{array}$ & $\begin{array}{l}\text { Uric acid } \\
(\mathrm{mg} / \mathrm{dl})^{+}\end{array}$ \\
\hline Weight (Kg) & & & $0,89^{* *}$ & $0,73^{* *}$ & & & & $0,32^{* * * *}$ \\
\hline $\begin{array}{l}\text { Waist circumference } \\
(\mathrm{cm})\end{array}$ & $0,74^{* * *}$ & $0,89^{* *}$ & $0,71^{* *}$ & $0,81^{* *}$ & $0,37^{* *}$ & $0,33^{* * *}$ & $0,5^{* * *}$ & \\
\hline $\begin{array}{l}\text { Systolic blood pressure } \\
(\mathrm{MmHg})\end{array}$ & & & & & & & $0,69^{* *}$ & \\
\hline Uric acid (mg/dl) & & $0,5^{* * * *}$ & & & & & & \\
\hline $\begin{array}{l}\text { Ultra sensitive C } \\
\text { reactive protein }(\mathrm{mg} / \mathrm{dl})\end{array}$ & & & & & & & & $0,48^{* *}$ \\
\hline
\end{tabular}

\section{Discussion}

This study is one of the first reports on the prevalence of metabolic syndrome and its correlation with ultrasensitive C-reactive protein and uric acid in Cartagena city. The obtained analyzes are congruent on which the general population presented a high obesity index, attributing this basically to a sedentary lifestyle (Rodríguez \& García, 2016). Several studies report that the intake of high-calorie diets and saturated fats, but low in fiber, has become in recent years a constant practice in developing countries; together with the sedentary lifestyle resulting from the urbanization process, they have created the conditions for the increase of the frequency of obesity, especially abdominal, which are modifiable factors, typical of the individual (López-Jaramillo, Pradilla, Castillo, \& Lahera, 2007; Márquez-Sandoval, Bulló, Vizmanos, Casas-Agustench, \& Salas-Salvadó, 2008; Soca, 2009; Matía Martín, Lecumberri Pascual, \& Calle Pascual, 2007). It is acknowledge that there are no organized programs to prevent these risk factors and promote healthy habits. 
The prevalence of Metabolic Syndrome found in the study was $18 \%$, a value that agrees with the prevalence found in studies done by Manzur F., which was $22 \%$, in a population of the municipality of Arjona, using in this study the ATP III AHA criteria (Manzur, de la Ossa, Trespalacios, Abuabara, \& Lujan, 2008), along with Lizarazu I, who reported a prevalence of $23 \%$ on a group of people between 40 and 60 years, the average age of workers in her study participants was 51.3 years (Lizarazu Díazgranados, Rossi Trespalacios, Iglesias Acosta, \& Mendoza Torres, 2010). In the study conducted by Manzur, the socioeconomic level agrees with the one used in the present study as well as the age being that $84 \%$ were under 58 years of age (Manzur et al., 2008).

Regarding sex, the prevalence found was higher in women with $72 \%$. These data are similar to those reported by the Navarro E study, in which $78.7 \%$ prevalence was in women (Mody, Joshi, Khera, Ayers, \& Rohatgi, 2016; Ridker, Rifai, Rose, Buring, \& Cook, 2002). This may be due to the fact that the majority of the working population is male and the survey was carried out during working hours, which does not affect the reliability of the results; in previous studies no significant difference in prevalence between men and women has been demonstrated. It differs with the results found by Lizarazu I, where the prevalence of metabolic syndrome was higher in men than in women (Lizarazu Díazgranados et al., 2010).

The most prevalent component of the metabolic syndrome in the study was abdominal obesity within the metabolic syndrome group with $85 \%$, being similar to those reported by Manzur F, where abdominal obesity predominated in $70.27 \%$ in men and in $69.23 \%$ in women (Manzur et al., 2008). On the other hand Lizarazu, found that $93 \%$ of the respondents presented abdominal obesity (Lizarazu Díazgranados et al., 2010). It should be noted that the waist circumference used was not adjusted with our ethnic group, even though it was the most relevant component of the metabolic syndrome, which could be even greater when applying the new criteria, including the abdominal perimeter adapted to our ethnic group. Although in the study this prevalence is maintained, an increase could be observed when the cut-off point that defines abdominal obesity decreases, thus improving sensitivity, but worsening the specificity, by diagnosing people who eventually do not have metabolic syndrome. However, it was found that hyperglycemia is higher in men due to not complying with any type of diet or physical exercise regime which leads to an increase in body index, where it is common to find these elements increased in women over 55 especially with menopause with polycystic ovarian syndrome (Tovar \& Celemin, 2016; Pulido et al., 2016; 2011).

The plasma levels of ultrasensitive C-reactive protein were found significantly higher in susceptible people than in those who are not, confirming the relationship of this paremeter with the metabolic syndrome; However, statistically no strong correlation was found in either men or women with ultrasensitive C-reactive protein, glucose values, lipids and anthropometric measurements, in susceptible persons for metabolic syndrome, deferring this with the results obtained by Ridker and Matesanz, who found weak significant relationship with the data of C-reactive protein and lipid profile (Matesanz Ruiz et al., 2006; Ridker, Buring, Cook, \& Rifai, 2003; Ridker et al., 2002).

In general, the correlation found between ultrasensitive C-reactive protein and lipid levels in men and women has been weak, but without statistical significance. Although, it is necessary to highlight the usefulness of C-reactive protein as a strong predictor of cardiovascular risk, also the technique for its determination is affordable and can be performed easily.

Regarding the correlation analysis, none of the results showed statistical significance between uric acid in people susceptible to metabolic syndrome, except for women, differing from the study conducted by Jiménez which show that the prevalence of metabolic syndrome increases significantly with the increase in uric acid concentrations. Even so, it remains undetermined the lower excretion of uric acid in patients with metabolic syndrome and its association with systemic diseases (Fernández, 2016; Jiménez et al., 2009; Tovar \& Celemin, 2016).

\section{Conclusion}

When applying the ATP III criteria, the prevalence of metabolic syndrome is high and very similar to that found in other studies in Colombia, becoming a basis for further studies. It should be noted that despite the increase in the abdominal perimeter, these patients had a lower mean blood pressure than that established by the ATP III for metabolic syndrome, it could be said that the cardiovascular risk can start from values lower than those required by this criterion. Although a significant relationship was not found between uric acid and ultrasensitive C-reactive protein with the variables studied, it continues to be documented about the coexistence of these two factors with the Metabolic Syndrome.

\section{Financing}

Internal contest Rafael Núñez University Corporation. Cartagena de Indias/Colombia. 


\section{Competing Interests Statement}

The authors declare that there are no competing or potential conflicts of interest.

\section{References}

Aguilar, M., Bhuket, T., Torres, S., Liu, B., \& Wong, R. J. (2015). Prevalence of the metabolic syndrome in the United States, 2003-2012. Jama, 313(19), 1973-1974. https://doi.org/10.1001/jama.2015.4260

Arias, C., Valdivieso, R., Núñez, M., Inga, M., Sosa, F., \& Acosta, O. (2011). Evaluación del índice de masa corporal y su relación con la hiperglucemia en pacientes diabéticos tipo 2, en Lima Metropolitana, durante el año 2011. In Anales de la Facultad de Medicina, 73, 48. https://doi.org/10.15381/anales.v73i1.2224

Association, A. D. (2015). Diagnosis and classification of diabetes mellitus. Diabetes Care, 37(Supplement 1), S81-S90. https://doi.org/10.2337/dc15-S005

Ballantyne, C. M., Hoogeveen, R. C., Bang, H., Coresh, J., Folsom, A. R., Chambless, L. E., ... Boerwinkle, E. (2005). Lipoprotein-associated phospholipase A2, high-sensitivity C-reactive protein, and risk for incident ischemic stroke in middle-aged men and women in the Atherosclerosis Risk in Communities (ARIC) study. Archives of Internal Medicine, 165(21), 2479-2484. https://doi.org/10.1001/archinte.165.21.2479

Bell Castillo, J., George Carrión, W., García Céspedes, M. E., Delgado Bell, E., Bell, G., \& de Jesús, M. (2017). Identificación del síndrome metabólico en pacientes con diabetes mellitus e hipertensión arterial. MEDISAN, 21(10), 3038-3045.

Biben, S., Orkin, S., \& Bopp, C. (2016). Prevalence of Metabolic Syndrome Risk Factors in College-Aged Students. In International Journal of Exercise Science: Conference Proceedings, 9, 20.

Borghi, C., Rosei, E. A., Bardin, T., Dawson, J., Dominiczak, A., Kielstein, J. T., .. Mancia, G. (2015). Serum uric acid and the risk of cardiovascular and renal disease. Journal of Hypertension, 33(9), 1729-1741. https://doi.org/10.1097/HJH.0000000000000701

Cabalé Vilariño, M. B., Sánchez Serrano, D., Gutiérrez Carbonell, E., \& Flores Sánchez, A. (2011). Prevalencia del síndrome metabólico en pacientes dislipidémicos con antecedentes de revascularización miocárdica. Revista Cubana de Investigaciones Biomédicas, 30(4), 464-470.

Carvajal, C. C. (2017). Sindrome metabólico: Definiciones, epidemiología, etiología, componentes y tratamiento. Medicina Legal de Costa Rica, 34(1), 175-193.

Castro, C., \& Yaqueline, Y. (2016). Identificación de síndrome metabólico y comparación de las escalas Adult Treatment Panel III The National Cholesterol Education Program (ATP-III) y la Federación Internacional de la Diabetes (FID) en pacientes que acuden a chequeos ejecutivos en el Hospital de los Valles. PUCE.

Culleton, B. F., Larson, M. G., Kannel, W. B., \& Levy, D. (1999). Serum uric acid and risk for cardiovascular disease and death: the Framingham Heart Study. Annals of Internal Medicine, 131(1), 7-13. https://doi.org/10.7326/0003-4819-131-1-199907060-00003

Díaz, M. S. (2015). Actualización 2015 del algoritmo ADA/EASD de tratamiento de la hiperglucemia. Diabetes Care, 38(1), 140-149.

Esser, N., Legrand-Poels, S., Piette, J., Scheen, A. J., \& Paquot, N. (2014). Inflammation as a link between obesity, metabolic syndrome and type 2 diabetes. Diabetes Research and Clinical Practice, 105(2), 141-150. https://doi.org/10.1016/j.diabres.2014.04.006

Expert Panel on Detection, E. (2001). Executive summary of the Third Report of the National Cholesterol Education Program (NCEP) expert panel on detection, evaluation, and treatment of high blood cholesterol in adults (Adult Treatment Panel III). Jama, 285(19), 2486. https://doi.org/10.1001/jama.285.19.2486

Fernández, A. G. (2016). Proteína c reactiva, índice de conicidad y factores de riesgo cardiovascular en pacientes con diabetes tipo 2. Universidad Complutense de Madrid.

Garg, P. K., Norby, F. L., Polfus, L. M., Boerwinkle, E., Gibbs, R. A., Grove, M. L., ... Hoogeveen, R. C. (2017). Lipoprotein-associated phospholipase A 2 and risk of incident peripheral arterial disease: Findings from the Atherosclerosis Risk in Communities study (ARIC). Atherosclerosis. https://doi.org/10.1016/j.atherosclerosis.2017.11.007

Giraldo, N. A. G., Perdomo, A. M. Z., Aristizábal, T. S. T., \& Restrepo, A. E. (2017). Síndrome metabólico en un grupo de adultos mayores no institucionalizados según criterios de organismos internacionales. Perspectivas En Nutrición Humana, 18(1), 25-35. http://dx.doi.org/10.17533/udea.penh.v18n1a03 
Han, T. S., Sattar, N., Williams, K., Gonzalez-Villalpando, C., Lean, M. E., \& Haffner, S. M. (2002). Prospective study of C-reactive protein in relation to the development of diabetes and metabolic syndrome in the Mexico City Diabetes Study. Diabetes Care, 25(11), 2016-2021. https://doi.org/10.2337/diacare.25.11.2016

Heiss, G., Snyder, M. L., Teng, Y., Schneiderman, N., Llabre, M. M., Cowie, C., ... Gallo, L. (2014). Prevalence of metabolic syndrome among Hispanics/Latinos of diverse background: the Hispanic Community Health Study/Study of Latinos. Diabetes Care, 37(8), 2391-2399. doi:https://doi.org/10.2337/dc13-2505

Iliff, D. (2001). Guidelines for diagnosis and treatment of high cholesterol. JAMA, 286(19), 2400-2401; author reply 2401-2402. https://doi.org/10.1001/jama.286.19.2398

Jiménez, A. E. R., Navarro, J., Islas, M. C., DFranchis, L. J. C., Gómez, J. L., Pichardo, C. N., .. López, F. R. E. (2009). Prevalencia del síndrome metabólico en relación con las concentraciones de ácido úrico. Medicina Interna de México, 25(4), 278-284.

Jossa, F., Farinaro, E., Panico, S., Krogh, V., Celentano, E., Galasso, R., ... Trevisan, M. (1994). Serum uric acid and hypertension: the Olivetti heart study. Journal of Human Hypertension, 8(9), 677-681.

Kahn, R. (2003). Follow-up report on the diagnosis of diabetes mellitus: the expert committee on the diagnosis and classifications of diabetes mellitus. Diabetes Care, 26(11), 3160. https://doi.org/10.2337/diacare.26.11.3160

Kang, D.-H., \& Nakagawa, T. (2005). Uric acid and chronic renal disease: possible implication of hyperuricemia on progression of renal disease. In Seminars in nephrology (Vol. 25, pp. 43-49). https://doi.org/10.1016/j.semnephrol.2004.10.001

Lizarazu Díazgranados, I., Rossi Trespalacios, C., Iglesias Acosta, J., \& Mendoza Torres, E. (2010). Síndrome metabólico en trabajadores de la Universidad Libre Seccional Barranquilla, 2009. Salud Uninorte, 26(1), 41-53.

López-Jaramillo, P., Pradilla, L. P., Castillo, V. R., \& Lahera, V. (2007). Patología socioeconómica como causa de las diferencias regionales en las prevalencias de síndrome metabólico e hipertensión inducida por el embarazo. Revista Española de Cardiología, 60(2), 168-178. https://doi.org/10.1157/13099463

Manzur, F., de la Ossa, M., Trespalacios, E., Abuabara, Y., \& Lujan, M. (2008). Prevalencia de síndrome metabólico en el municipio de Arjona, Colombia. Revista Colombiana de Cardiología, 15(5), 215-222.

Márquez-Sandoval, F., Bulló, M., Vizmanos, B., Casas-Agustench, P., \& Salas-Salvadó, J. (2008). Un patrón de alimentación saludable: la dieta mediterránea tradicional. Antropo, 16, 11-22.

Matesanz Ruiz, C., Caro de Miguel, C., Campos, F., Gómez de Terreros Caro, J., Ariñez Fernández, C., \& Gutiérrez Ortega, C. (2006). Descripción del valor de la proteína C reactiva según dislipemia e historia de tabaquismo. Prevención Del Tabaquismo, 8(1), 18-24.

Matía Martín, P., Lecumberri Pascual, E., \& Calle Pascual, A. L. (2007). Nutrición y síndrome metabólico. Revista Española de Salud Pública, 81(5), 489-505. https://doi.org/10.1590/S1135-57272007000500006

Melnyk, O. O. (2017). Metabolic syndrome and the risk of chronic kidney disease. KIDNEYS, 6(2), 80-90. https://doi.org/10.22141/2307-1257.6.2.2017.102785

Mody, P., Joshi, P. H., Khera, A., Ayers, C. R., \& Rohatgi, A. (2016). Beyond coronary calcification, family history, and C-Reactive protein: cholesterol efflux capacity and cardiovascular risk prediction. Journal of the American College of Cardiology, 67(21), 2480-2487. https://doi.org/10.1016/j.jacc.2016.03.538

Pineda, C. A. (2008). Síndrome metabólico: definición, historia, criterios. Colombia Médica, 39(1), 96-106

Pulido, D. I., Scott, M. L., Barreras, C., Soto, F., Barrios, C., \& López, C. M. (2016). Síndrome de ovario poliquístico en mujeres portadoras de síndrome metabólico. Revista Médica Clínica Las Condes, 27(4), 540-544. https://doi.org/10.1016/j.rmclc.2016.07.013

Ridker, P. M., Buring, J. E., Cook, N. R., \& Rifai, N. (2003). C-reactive protein, the metabolic syndrome, and risk of incident cardiovascular events. Circulation, 107(3), 391-397. https://doi.org/10.1161/01.

Ridker, P. M., Rifai, N., Rose, L., Buring, J. E., \& Cook, N. R. (2002). Comparison of C-reactive protein and low-density lipoprotein cholesterol levels in the prediction of first cardiovascular events. New England Journal of Medicine, 347(20), 1557-1565. https://doi.org/10.1056/NEJMoa021993

Rodríguez, R. G., \& García, J. C. (2016). Hábitos de vida saludables en el síndrome metabólico. Medimay, 22(1), 102-106. 
Rosales, L., Rivas, E. T., \& Troconis, T. J. B. (2017). Estudio de la relación entre las características genéticas asociadas a la leptina y el síndrome metabólico. Caso de un grupo familiar con evidencias de trastorno. Acta Bioclínica, 7(14), 145-168.

Sakkinen, P. A., Wahl, P., Cushman, M., Lewis, M. R., \& Tracy, R. P. (2000). Clustering of procoagulation, inflammation, and fibrinolysis variables with metabolic factors in insulin resistance syndrome. American Journal of Epidemiology, 152(10), 897-907. https://doi.org/10.1093/aje/152.10.897

Soca, P. E. M. (2009). El síndrome metabólico: un alto riesgo para individuos sedentarios. Acimed, 20(2), 0.

Srikanthan, K., Feyh, A., Visweshwar, H., Shapiro, J. I., \& Sodhi, K. (2016). Systematic review of metabolic syndrome biomarkers: a panel for early detection, management, and risk stratification in the West Virginian population. International Journal of Medical Sciences, 13(1), 25. https://doi.org/10.7150/ijms.13800

Testa, R., Vanhooren, V., Bonfigli, A. R., Boemi, M., Olivieri, F., Ceriello, A., ... Bacalini, M. G. (2015). $\mathrm{N}$-glycomic changes in serum proteins in type 2 diabetes mellitus correlate with complications and with metabolic syndrome parameters. PLoS One, 10(3), e0119983. https://doi.org/10.1371/journal.pone.0119983

Tovar, A. P., \& Celemin, C. (2016). Menopausia y síndrome metabólico. RFS, 7(1), 69-76. http://dx.doi.org/10.25054/rfs.v7i1.183

Valenzuela, A. (2016). Ácido úrico:?’ un nuevo factor contribuyente al desarrollo de obesidad? Revista Chilena de Nutrición, 43(3), 303-307. http://dx.doi.org/10.4067/S0717-75182016000300011

Virtanen, M., Ferrie, J. E., Akbaraly, T., Tabak, A., Jokela, M., Ebmeier, K. P., ... Kivimäki, M. (2017). Metabolic Syndrome and Symptom Resolution in Depression: A 5-Year Follow-Up of Older Adults. J Clin Psychiatry, 78(1), e1-e7. https://doi.org/10.4088/JCP.15m10399

\section{Copyrights}

Copyright for this article is retained by the author(s), with first publication rights granted to the journal.

This is an open-access article distributed under the terms and conditions of the Creative Commons Attribution license (http://creativecommons.org/licenses/by/4.0/). 